\title{
THE CRIME OF MONEY LAUNDERING WITH THE ORIGIN CRIMINAL ACTION OF DRUG TRAFFICKING IN SUPREME COURT DECISION No. 1303 K / PID. SUS / 2013 JUNCTO HIGH COURT DECISION No. 700 / Pid / 2012 / PT.MDN JUNCTO MEDAN DISTRICT COURT DECISION No.1234 / Pid.B / 2012 PN. Mdn
}

\author{
Ferdy Saputra \\ Faculty of Law, Malikussaleh University \\ ferdysaputraagani@ymail.com
}

\begin{abstract}
Pencucian uang or in English is called money laundering is not only threatening the economic stability and integrity of the financial system, but also harm the joints of the life of society, nation, and state based on Pancasila and the Constitution of the Republic of Indonesia Year 1945 Money laundering is done is to disguise the proceeds of crime. In this case, will be appointed on the crime of narcotics and drugs. This research uses a normative juridical research with descriptive analysis. The type of data used is secondary data sourced from primary, secondary and tertiary legal materials. Secondary data were collected by library research techniques. Next, the data is analyzed using qualitative analysis methods. Mode of crime in the banking sector, in this case, use money transfer services Money Changer (money changers). Predicate crime (crimes origin) it is a criminal offense drug, namely methamphetamine. Methamphetamine trade is carried out between cross country, namely between Malaysia and Indonesia.
\end{abstract}

Keywords : Money, Laundering, Predicate, Crime, Narcotics.

\section{INTRODUCTION}

Since a long time ago, the crime of drug trafficking was ensured about money laundering process. The development of money laundering typology points out the illicit drug market as the most dominant of crime's cause (predicate crime) of money laundering. Organized crime uses money laundering method to hide, disguise or obscure the proceeds of business activity appears legitimate. Furthermore, the proceeds of drug trafficking are used for illegal purpose as similar case or growing new crimes. ${ }^{1}$

Generally crime of money laundering uses banking sector to derive criminal activity. Hiding or disguising the origin of wealth obtained illegally from criminal activity is to impede law enforcement officers to trace it, in matter using of wealth obtained from criminal activity enable to use it freely for legal or illegal purpose. Money laundering activity involves banking transfers or commercial transaction

${ }^{1}$ Yunus Husein, "The Relationship Between the Illicit Circulation of Drugs and the Crime of Money Laundering", supporting paper of the Indonesian Delegation to the ForthySeventh Session of the Commission on Narcotics Drugs, held in Vienna March 15-22, 2004, p. 1. 
because this institution deals with global payments system regarding electronic funds transfer. Proceeds of crime in general comes in large numbers even the movement of funds passes national border to use banking secrecy to protect them which becomes bank's duty. ${ }^{2}$

Money laundering not only threats economic stability integrity of financial system but also the principle of social, national and political life based on Pancasila and The 1945 Constitution of The Republic Indonesia. ${ }^{3}$ Money laundering is the illegal process of concealing the origins of money. ${ }^{4}$ In case this study carries out about crime of drug trafficking and illicit drug market. The proceed money of crime of drug trafficking is concealing to appear as legitimate. Drug markets to user then the proceed derives as if legal regarding to run legal business. In that way the drug trafficking proceed is disguised that is commonly named money laundering. ${ }^{5}$

${ }^{2}$ M. Zainul Hafizi, "Business Ethics Paper for Law Enforcement on Money Laundering in Indonesia", (Jakarta: Indraprasta University, PGRI, 2011). See also: definition of Bank Secrecy in Article 1 number 28 of Law No. 10 of 1998 concerning Banking.

${ }^{3}$ Part Considering letters a. Law No. 8 of 2010 concerning Prevention and Eradication of Money Laundering Crimes.

${ }^{4}$ Peter Reuter and Edwin M. Truman, Chasing Dirty Money: The Fight Against Money Laundering, (US: Automated Graphic Systems, Inc., 2004), p. 1-8. See also: PPATK E-Learning, "E-Learning Module 1: Introduction to Anti-Money Laundering and Terrorism Funding", (Jakarta: PPATK, no year), p. 1-10.

Lucky Nurhadiyanto, "Pola Pencucian Uang Hasil Perdagangan Narkoba dan Pembalakan Liar", Indonesian Criminology Journal, Vol. 6, No. II, August 2010, p. 161.
In matter related with the case of this research, the crime of money laundering with the origin criminal action of drug trafficking in Supreme Court Decision No. 1303 K / PID. SUS / 2013 juncto High Court Decision No. 700 / Pid / 2012 / PT.MDN juncto Medan District Court Decision No.1234 / Pid.B / 2012 PN. Mdn, the modus of crime in banking, int this case, uses sending money services at money changer. The predicate crime of this kind is mostly such as crystal meth. Illicit crystal meth market links between to Malaysia and Indonesia.

Supreme Court Decision No. 1303 K / PID. SUS / 2013 juncto High Court Decision No. 700 / Pid / 2012 / PT.MDN juncto Medan District Court Decision No.1234 / Pid.B / 2012 PN. Mdn at October $8^{\text {th }}$ 2012, theses decision is interesting to to study because the decision at the District Court level in his ruling that imposed a prison sentence against Defendant Maha Nathy Naidu alias Rendy with imprisonment for 3 (three) years and 6 (six) months and a fine of $\mathrm{Rp}$. $1,000,000,000$ (one billion rupiah) subsidair 4 (four) months in prison. Whereas, at the High Court level decision Defendant Maha Nathy Naidu was sentenced by the Panel of Judges with imprisonment for 6 (six) years and a fine of Rp. 2,000,000,000 (two billion rupiah) and if the fine is not paid, it can be replaced with imprisonment for 6 (six) months. Furthermore, in a court decision at the Supreme Court level, it was decided by his sentence to sentence the Defendant to a prison sentence of 6 (six) months and a fine of Rp. 37,000,000,000 (thirty seven billion rupiah). This difference in calculation of fines is interesting to study, regarding where the High Court Judges 


\section{LAW REVIEW $\begin{aligned} & \text { E-ISSN: 2722-3663 } \\ & \text { Volume } 1 \text {, Isue 1, May 2020 }\end{aligned}$}

came from to decide to raise the fine from Rp. 1 billion to Rp. 2,000,000,000, - (Two Billion Rupiah), while the Supreme Court of Justice at the Supreme Court sentenced the Defendant to a fine of $\mathrm{Rp}$. 37,000,000,000 (thirty-seven billion). Meanwhile, the Defendant's assets were not up to the amount desired by the Panel of Judges of Rp. 37 37,000,000,000, (Thirty-seven Billion).

Based on the description above, it can be seen that there is a relationship between money laundering and the world of drug crime. Therefore "The crime of money laundering with the origin criminal action of drug trafficking in Supreme Court Decision No. 1303 K / PID. SUS / 2013 juncto High Court Decision No. 700 / Pid / 2012 / PT.MDN juncto Medan District Court Decision No.1234 / Pid.B / 2012 PN. Mdn" is interesting to be studied dan researched. The problem derives from this study: how is the juridical analysis of money laundering crime and predicate crime of durg trafficking crime basen on Medan District Court Decision No.1234 / Pid.B / 2012 PN. Mdn.

\section{METHOD}

Legal research is a process to find the rule of law, legal principles, and legal doctrines to address the legal issues at hand. ${ }^{6}$ The type of legal research used in this study is normative juridical. The data used are secondary data using primary legal materials, secondary legal materials, and tertiary legal materials.

\footnotetext{
${ }^{6}$ Peter Mahmud Marzuki, Penelitian
} Hukum, (Jakarta: Kencana Prenada Media Group, 2005), hlm. 35.

\section{DISCUSSION}

In Indonesia, the criminalization of money laundering takes time, it can be seen by looking at efforts to deal with money laundering in Indonesia, which began since the enactment of Law No. 15 of 2002 concerning Criminal Action of Money Laundering as amended by Law No. 25 of 2003 concerning Amendments to Law No. 15 of 2002 concerning Criminal Action of Money Laundering, which was later also amended by a new law namely Law No. 8 of 2010 concerning the Countermeasure and Eradication of Money Laundering.

Provisions regarding the evidence in Law No. 8 of 2010 concerning the Countermeasure and Eradication of Money Laundering have arranged special provisions regarding the provisions of proof carried out at the time of the hearing at the hearing. Examination of that provision is regulated in Law No. 8 of 2010 concerning the Countermeasure and Eradication of Money Laundering regulated in Articles 77 and 78 which is about the provision of examination of reverse

The provisions of reverse examination are regulated in article 77 Law No. 8 of 2010 concerning the Countermeasure and Eradication of Money Laundering, stated "For the interest of the examination in the trial, the defendant shall be obliged to evidence that his/ her Assets is not the result of criminal action".

The provision based on article 78 Law Law No. 8 of 2010 concerning the Countermeasure and Eradication of Money Laundering:

1. When the examination in the trial as set forth in Article 77 above, the judge 


\section{LAW REVIEW $\begin{aligned} & \text { E-ISSN: 2722-3663 } \\ & \text { Volume } 1 \text {, Isue 1, May 2020 }\end{aligned}$}

orders the defendant in order to evidence that his/ her Assets are not from or are not associated with the criminal action as set forth in Article 2 section (1)

2. The defendant evidences that his/ her Assets are not from or are not associated with the criminal action as set forth in Article 2 section (1) through proposing the sufficient items of evidences.

As the rule of examination above, examination process of criminal crime of money laundering looks easy carried out by the defendant. This ease caused examination obliged to defendant in trial. This matter related reverse examination process gives out effectiveness to prove defendant is guilty or not.

According to R. Soesilo, regarding the system or theory of examination there are 4 (four) types: ${ }^{7}$

1. Examination system according to positive law;

According to this system, a number of evidences that have been determined by law are false or not. According to this regulation the judge's job is merely to match whether the amount of evidence that has been set out in the law already exists, if he does not need to ask the contents of his heart (sure or not), the suspect must be declared wrong and convicted. In this system the judge's belief does not take part at all, but the law, in power here

2. Examination system according to the negative law;

${ }^{7}$ R. Soesilo, Kitab Undang-Undang Hukum Pidana Serta Komentar-Komentar Lengkap Pasal Demi Pasal, (Bogor : Politeia, 1985), p. 6- 8.
According to this system the judge can only sentence, if at least the amount of evidence that has been determined is a law exists, coupled with the judge's conviction of the accused's wrongdoing of a criminal event allegedly against him. Although the evidence is complete, if the judge is not sure about the defendant's guilt, then, it must be decided freely. In this system the law is not the ruling but the judge, but the power is limited by law.

3. Examination system according to negative law;

According to this system the judge can only sentence, if at least the amount of evidence that has been determined is a law exists, coupled with the judge's conviction of the accused's wrongdoing of a criminal event allegedly against him. Although the evidence is complete, if the judge is not sure about the defendant's guilt, then, it must be decided freely. In this system the law is not the ruling but the judge, but the power is limited by law.

4. Free examination system;

According to this system, the law does not determine regulations such as the evidentiary system that must be obeyed by judges, this system assumes or also recognizes the existence of certain evidences, but these evidences are not stipulated in laws such as the evidentiary system according to the law positive laws and proof systems according to negative laws. In determining the types and the number of evidences that are deemed sufficient to determine the defendant's mistakes, the judge has full discretion. He is free to set it. The regulation that binds him 
is that in his decision he must also state the reasons.

5. The examination system Is only based on mere belief.

According to this system the judge is not bound by certain evidences, he decided, the defendant's mistake was based solely on his conviction. In this case the judge has complete freedom without being controlled at all. Of course there is always a logical reasoning, which results in a judge having an opinion about whether or not the situation is proven. The problem is that in this system the judge is not required to mention the reasons and if the judge mentions the evidence he uses, the judge can use any evidence. The existence of this system is that there is contained too much confidence in the mere determination of individual impressions of a judge. Supervision of judges 'decisions such as this is difficult to do, because the regulatory body cannot know the judges' considerations, which direct the judge's opinion towards the decision

\section{The Relationship of Money Laundering Crimes with Drugs as the predicate Crimes}

After discussing the examination theories in criminal procedural law, the question arises that what is the current system used in Indonesia? Article 183 of Indonesia Criminal Procedure Code is determined: "A judge may not convict a person unless if at least two legal instruments prove he believes that a crime has actually taken place and that the defendant is guilty of committing it". Based on Article 183 of Indonesia Criminal Procedure Code, the criminal procedure law in Indonesia uses a proof system according to negative laws. Therefore, the system of proof adopted is a system of proof "negatief wettelijk stelsel".

This examination system "negatief wettelijk stelsel" must: Error proven by at least "two valid pieces of evidence"; and with the legal minimum evidence the judge

obtains confidence that a crime has occurred and the defendant is the culprit.

Regarding the examination law regarding the handling of money laundering crimes, Law No. 8 of 2010 concerning the Countermeasure and Eradication of Money Laundering regulates the type and strength of evidence wider than the formula contained in the Criminal Procedure Code. In the Law No. 8 of 2010 concerning the Countermeasure and Eradication of Money Laundering besides the evidences listed in Article 184 of the Criminal Procedure Code, also added with other evidences as stipulated in Article 73 of Law No. 8 of 2010 concerning the Countermeasure and Eradication of Money Laundering, that the legal evidence in evidencing:

1. Evidence as referred to in the Criminal Procedure Code, namely: Witness Statement; Expert Statement; Letter; Hints; Defendant's Statement; and

2. Other evidence in the form of information that is spoken, sent, received, or stored electronically with optical devices or similar devices such as optics and documents. Article 1 Number 16 of the TPPU Law stipulates that documents are data, records or information that can be seen, read and / or heard that can be issued with or without the help of a means, whether stated on paper or any physical object 
other than paper or electronically recorded, including but not limited to: writing, sound, or drawing; map, design, photograph, or the like; and letters, signs, numbers, symbols or perforations that have meaning or can be understood by people who are able to read or understand them.

The use of Law No. 8 of 2010 concerning Countermeasure and Eradication of Money Laundering is very urgent for the effectiveness of proving narcotics crime. Moreover, law enforcement in Indonesia, whether the Police or the Attorney General's Office is still educated, raised and practiced the old paradigm in proof. Law enforcement in Indonesia still adheres to the follow the suspect paradigm. That is, to prove narcotics crime, law enforcement relies more on the testimony of perpetrators or other people who know it, where the most important thing is witnesses. But this approach is not enough to prove the growing narcotics cases. Narcotics offenders who understand financial market instruments understand how banks work and know various investment products, it will be easy to cover the traces of the results of narcotics crimes. By laundering the money, the crime he committed will not be revealed.

The more specific legal provisions are based on the legal principle of lex specialis systematic derogat lex generali (the principle of systematic specificity of law). This means that a specific criminal provision is valid if the legislator really intends to enforce the criminal provision as a specific criminal provision. Therefore, if it is related to the court's decision above, the Panel of Judges who examined, tried, and decided the case was correct in applying the law because the lex specialis systematic principle requires law enforcers to use more specific regulations, this is because in the case the original criminal act was a narcotics crime because it had been good and right to decide using Law No. 35 of 2009.

Narcotics crime is included in the category of motivating "economic gain" or generating economic profits, especially carried out by corporations or criminal organizations or syndicates. It is certain to synergize with money laundering to obscure the proceeds of crime. Coordination between law enforcement agencies is needed in dealing with criminal agreements in drug crimes with money laundering because indeed the results of narcotics crime promise very big profits. ${ }^{8}$

The need for law enforcement synergy between National Anti-Narcotics Agency (BNN) investigators, Indonesian National Police in cooperation with Indonesian Financial Transaction Reports and Analysis Centre (PPATK) and banks to trace financial transactions carried out by both individual and corporate actors using the "follow the money" approach. From the tracking and analysis results of the PPATK, it will be known the flow of funds or transfers and who did it, whether individuals or corporations. If the perpetrators of the corporation, then it is necessary to examine who is responsible whether the corporate management, controllers or people who carry out orders for and on behalf of the interests of the corporation or "corporate liability".

${ }^{8}$ Djoko Sarwoko in the Republika Daily, "Between Narcotics and Money Laundering", published Saturday, 23 November 2013. 


\section{LAW REVIEW $\begin{aligned} & \text { E-ISSN:2722-3663 } \\ & \text { Volume } 1 \text {, Issue } 1 \text {, May 2020 }\end{aligned}$}

Investigation of these assets needs to be developed if the results are significant, where should the financial transactions be tracked by requesting reports on the results of the assets of the child and his wife as in Article 97 and Article 98 of Law No. 35 of 2009 concerning Narcotics. Or is there a possibility that the proceeds of narcotics crime will be used to fund terrorism activities. This needs to be examined because the possibility of proceeds of crime is used to assist terrorist activities, especially if the perpetrators are corporations, narcotics dealers, syndicates, or criminal organizations.

In dealing with drug crimes and TPPU, the legal process is hampered by a law that does not regulate the case under one roof, which is separated between Law No. 35 of 2009 concerning Narcotics and Law No. 8 of 2010 concerning Countermeasure and Eradication of Money Laundering.

Indictments of money laundering in drug cases can be arranged in the form of subsidarity because the existing laws are still in conflict with the authority of investigators to handle both different but related cases.

In Article 137 of Law No. 35 of 2009 regulates specific minimums, whereas Law No. 8 of 2012 does not regulate it. Actually Article 137 of Law No. 35 of 2009 concerning Narcotics substantially contains elements similar to elements in Article 3 of Law No. 8 of 2010 concerning Prevention and Eradication of Money Laundering. Therefore, the TPPU indictment can be arranged in the form of subsidarity in the past money laundering indictment because BNN obtained a TPPU investigation based on Article 74 of Law
No. 8 of 2010, then subsidairnya Article 137 of Law No. 35 of 2009 concerning Narcotics. So that BNN Investigators can still carry out TPPU investigations that are alleged to violate Article 137 letters a and b. Law No. 35 of 2009. From the historical aspect, why the legislators included Article 137 in Law No. 35 of 2009, due to anticipate if Article 74 of Law No. 8 of 2010 does not regulate the authority of the original criminal investigator $(\mathrm{BNN})$ to conduct a TPPU investigation. ${ }^{9}$

Although included in the TPPU, the results of narcotics crimes obscured through money laundering, the target subject is not as extensive as stipulated in Article 3 of Law No. 8 of 2010. Formulation of offense Article 3 of Law No. 8 of 2010 is said to have a broader target subject because it contains the phrase 'which is known or reasonably assumed to be the result of a criminal offense as referred to in Article 2 paragraph (1), there are 26 types of criminal acts including narcotics.

Article 137 letter b of Law No. 35 of 2009 which has been adopted in Article 4 of Law No. 8 of 2010 contains a heavier criminal threat, which is a maximum of 20 years imprisonment with a maximum fine of Rp. 5 billion and if the fine is not paid, it is replaced with a sentence of one year and four months. Heavier than Law No. 35 of 2009 which is subject to Article 30 paragraph (6) of Indonesia Criminal Code governing criminal imprisonment substitutes must not be from eight months.

In matter related to Medan District Court Decision No. 1243 / Pid.B / 2012 / PN.Mdn., Dated October 8, 2012 in this study, Defendant Maha Nathy Naidu alias

\footnotetext{
${ }^{9}$ Ibid.
} 


\section{LAW REVIEW $\begin{aligned} & \text { E-ISSN: 2722-3663 } \\ & \text { Volume } 1 \text {, Isue 1, May 2020 }\end{aligned}$}

Rendy was convicted based on Article 137 letter b. Law No. 35 of 2009 concerning Narcotics. Defendant Maha Nathy Naidu alias Rendy has been proven legally and convincingly as the person who received the placement, payment or expenditure, safekeeping, exchange, concealment or disguising investment, deposit or transfer, grant, inheritance, assets or money, objects or assets in the form of objects move or not move, tangible or intangible which is known to originate from narcotics crime and / or narcotics precursor crime. As for the main elements in the provisions of Article 137 letter b. The Defendant must know that the money he received is from narcotics crime.

Regarding the proof of the element "What He Knows Comes from Narcotics Crimes" is very difficult to prove because Defendant Maha Nathy Naidu alias Rendy did not know at all where the money came from. Defendant Maha Nathy Naidu only knew that the money he received was from the transfer of Mr. Kamal as a friend of his father Maha Nathy Naidu, namely Bayu who was engaged in the business of money changers. $\mathrm{Mr}$ Kamal's business also received money from Indonesian Migrant Workers (TKI) residing in Malaysia to be transferred to the families of Indonesian migrant workers in Indonesia. This is what was infiltrated by the drug mafia by making cooperation with $\mathrm{Mr}$ Kamal so that methamphetamine from Malaysia entered Indonesia through Tanjung Balai.

In investigating the crime of money laundering according to Law No. 8 of 2010 concerning Countermeasure and Eradication of Money Laundering, the party authorized to investigate money laundering is PPATK. Then, in this case, the PPATK has provided the results of its report to the North Sumatra National Narcotics Agency (BNN), so that eventually the BNN delegated the case to the North Sumatra High Prosecutor's Office for trial.

Juridical Analysis of Criminal Action of Money Laundering and Drugs Crime as Predicate Crimes in the Medan District Court Decision No. 1243 / Pid.B / 2012 / PN.Mdn., October $8^{\text {th }}, 2012$

Limitation of legal considerations in formal criminal law is defined as a stage where the panel of judges considers the facts revealed during the trial, starting from the indictment, exception, examination of evidence and witnesses, charges, pledoi, replicas, duplicates, decisions. The legal considerations also include articles from the legal regulations which form the basis of the decision. In practice, the basis on which a judge is made in a decision is systematized in the recall section. Legal considerations start with the word "weigh ... and so on".

In District Court Decision No. 1243 / Pid.B / 2012 / PN.Mdn., Dated 08 on behalf of Defendant Maha Nathy Naidu alias Rendy has been decided based on Article 137 letter b. Law No. 35 of 2009 concerning Narcotics. In its legal consideration, Defendant Maha Nathy Naidu alias Rendy was the person who received the placement in the form of a transfer of money which he knew came from a narcotic crime.

The element of "Receiving Placement in the form of Money Transfer" in the District Court Decision has been fulfilled with the consideration that: Defendant Maha Nathy Naidu alias Rendy has opened accounts in the name of himself, Namdewa, and W. Wijen Khrisna 


\section{LAW REVIEW $\begin{aligned} & \text { E-ISSN:2722-3663 } \\ & \text { Volume } 1 \text {, Issue 1, May 2020 }\end{aligned}$}

and uses these accounts to collect payments / transfers the money according to Defendant Maha Nathy Naidu was from Kamal's money transfer from Malaysia which came from the Indonesian Migrant Workers' money transfer, however, it turned out that it had been proven legally and convincingly Suryono alias Aweng who possessed goods in the form of crystal possession Anly Yusuf alias Mami from Ramli Petrus aka Abeng, Anly Yusuf alias Mami paid the meth payment to Ramli Petrus alias Abeng to the accounts of Defendants Maha Nathy Naidu, Namdewa, and W. Wijen Khrisna. Therefore, the element "Receiving Placement in the form of Money Transfer" has been fulfilled.

On consideration the panel of judges of the District Court has examined separate files, in the name of Suryono alias Aweng as the dealer of meth, Anly Yusuf alias Mami as the owner of meth which circulated Suryono alias Aweng, and Ramli Petrus alias Abeng as the leader of meth which ordered Anly Yusuf aka Mami to pay the methamphetamine to Defendant Maha Nathy Naidu alias Rendy, Namdewa, and W. Sesame Krishna.

Based on the Medan District Court Decision No. 470 / Pid.B / 2012 / PNMdn., Dated July 12, 2012 Jo. Decision of the Medan High Court No. 450 / Pid / 2012 / PT-Mdn., Dated 31 August 2012, Ramli Petrus aka Abeng Ramli Petrus alias Abeng has been proven legally and convincingly guilty of committing a crime:

1) Without the right and against the law to engage in evil agreements to sell and buy or submit Narcotics Group I in the form of non-plants weighing more than 5 grams.

2) Paying or spending money in the form of movable property originating from narcotics crime; Sentencing the Defendant with 8 (eight) years in prison and a fine of Rp. 1,500,000,000 (one billion five hundred million rupiah) provided that if the fine is not paid it will be replaced with a prison sentence of 6 (six) months.

Determine the period of detention that had been served by the Defendant deducted entirely from the criminal sentence;

Establish the Defendant remains in custody;

Determine that evidence is in the form of:

a. Narcotics of Group I non-plant species weighing 12.7 grams of the remaining of 1,197 grams that have been destroyed in accordance with the Minutes of Destruction of Evidence, dated January 4, 2012 totaling 1,184.3 grams and 1 (one) Nokia cellphone and 1 (one) suction fruit (bong) is seized to be destroyed;

b. Money of Rp. 6,100,000 (six million one hundred thousand rupiah) and $\mathrm{Rp}$. $45,000,000$ (forty five million rupiah) is confiscated for the State; c. 1 (one) KTP in the name of Ramli Petrus, 1 (one) SIM A in the name of Ramli Petrus and 1 (one) unit of Toyota Avanza platform number BL-1448-KW along with keys, STNK and BPKB returned to the Defendant.

The Judges who decided Anly Yusuf alias Mami's case had sentenced him to 10 years in prison. The verdict stated Defendant Anly Yusuf alias Mami had been proven legally and convincingly, committed a criminal act without rights and against the law, committed an evil agreement to trade Group I narcotics, not a plant that weighed more than 5 grams. Besides being declared in violation of 


\section{LAW REVIEW $\begin{aligned} & \text { E-ISSN: 2722-3663 } \\ & \text { Volume } 1 \text {, Isue 1, May 2020 }\end{aligned}$}

Article 114 paragraph (2) of Law No. 35 of 2009 concerning Jo Narcotics. Article 551 paragraph (1) of the Criminal Code, Mami is also declared to have violated Article 132 letter b. Law No. 35 of 2009, because it stores assets resulting from transactions obtained from narcotics crime. Anly Yusuf alias Mami was also fined Rp. 1,000,000,000 (one billion rupiah) which if not paid will be replaced with a prison sentence of 6 (six) months. The confiscated evidence was a Nokia C5 cellphone, Rp. 19,000,000.- (nineteen million), as well as 3.9 gram ear studs and returned the Defendant's SIM and ID card, a matter which relieved the Defendant that the Defendant was polite in the trial, and which incriminated the defendant was still in law, again carrying out the sentence in the case same. ${ }^{10}$

As a result of the actions of Anly Yusuf alias Mami, the Panel of Judges sentenced him, adding to the sentence Anly had to undergo in prison. Previously, this woman was also sentenced to 10 years in prison, for distributing methamphetamine drugs. Not long after serving his sentence at the Tanjung Gusta Women's Penitentiary, Anly was again arrested by BNN officers, together with Deputy Minister of Justice and Human Rights, Denny Indrayana who arrested her in prison on December 20, 2011, at around 3:30 WIB. Following the arrest of a number of his colleagues Ramli Petrus, and Suriono alias Aweng who was a courier or a member of his network. ${ }^{11}$

${ }^{10}$ Harian Berita Hukum, "Mami BD Shabu Sentenced to 10 Years in Prison", was published Thursday, July 12, 2012.

${ }^{11}$ Ibid.
Facts in the trial, Anly Yusuf claimed to have ordered his courier Suriono to take shabu-shabu from his colleague Ramli Petrus, in a separate file, and deliver the illegal goods to his customers in Medan. Orders are delivered via cellular telephone. Transactions occur repeatedly with the weight of methamphetamine in kilograms. Meanwhile, payments are made through a bank transfer bank account in the name of Anly's child. This case became a public concern, because in his claim the Prosecutor only stated that Anly violated Article 137 letter B of Law 35 of 2009, because he kept assets resulting from narcotics, such as the second primary indictment. Whereas in the 1 st primary charge, the Prosecutor also charged Anly with Article 114 paragraph (2) for distributing narcotics. This indictment is also in accordance with the facts at the trial. The prosecution reading hearing also invited suspicion. Because at that time the prosecutor in the trial lasted only a few minutes and in reading the charges read out very quietly. Finally the Panel of Judges has handed down their verdict on the Prosecutor's indictment and sentenced Anly. Both primary charges were proven and Anly was finally sentenced to 10 years in prison, just like the sentence he is currently undergoing due to a similar case. Anly was proven to repeat his actions in distributing narcotics. ${ }^{12}$

The case was revealed on December 21, 2011, when Deputy Minister of Justice and Human Rights, Denny Indrayana together with the National Anti-Narcotics Agency (BNN), managed to arrest Suryono alias Aweng,

${ }^{12}$ Ibid. 


\section{LAW REVIEW $\begin{aligned} & \text { E-ISSN: } 2722-3663 \\ & \text { Volume } 1 \text {, Issue 1, May 2020 }\end{aligned}$}

with evidence of 206.4 grams of methamphetamine. At Aweng's residence on Jalan Sengon Sekip, Medan, officers also succeeded in confiscating 0.5 grams of methamphetamine. The investigation revealed that the illicit goods belonged to Anly Yusuf alias Mami, who freely controlled drug trafficking in prison. After possessing strong evidence of the involvement of Anly Yusuf alias Mami, BNN finally made an arrest and seized Rp. 9 million, and mobile phones that were apparently used to regulate drug transactions in the Sumatra region. ${ }^{13}$

Mami Network outside the prison is not just Aweng. There are several other names that were also arrested, namely Ramli Petrus aka Abeng, who was arrested in August 2011 with evidence of methamphetamine weighing $1 \mathrm{~kg}$. From the investigation, Mami apparently controlled the sale of narcotics from prison, with details in October 2011 the methamphetamine transaction weighing 1 $\mathrm{kg}$, on December 17, 2011 there was also a purchase of methamphetamine weighing 1 $\mathrm{kg}$. Then on December 20, 2011, Mami contacted Aweng, ordered to take 200 grams of methamphetamine from the suspect Abeng and Alwi (already convicted). ${ }^{14}$

From there Mami again controlled the circulation of 206.4 grams of methamphetamine from the couriers. Mami ordered two couriers to share methamphetamine with Asiong weighing 50 grams, Rivet 50 grams, Said 100 grams. But when the arrest was made, Mami's three accomplices managed to escape, and

13 Medan Bisnis Daily, "Moko Sentenced to 8 Years", published Monday, November 4, 2013.

${ }^{14}$ Ibid. only Aweng was captured. In the prosecutor's indictment file, it turns out that methamphetamine was obtained by Mami from Abeng, and Tri Sudiatmoko alias Moko Prisoner of the Tanjung Gusta Adult Medan Medan in November 2011 weighing 2 ounces at a price of $\mathrm{Rp} 65$ million per ounce. ${ }^{15}$

The element "which he learned from narcotics crime" in the Medan District Court's ruling has been proven legally and convincingly for Defendant Maha Nathy Naidu to deliberately open bank accounts in the names of his siblings namely Namdewa and W. Wijen Khrisna so that they can receive money transfers from the confession of Anly Yusuf alias Mami who paid the methamphetamine to the accounts opened by Defendant Maha Nathy Naidu alias Rendy. Therefore, the element "What He Knows From Narcotics Crimes" has been proven legally and convincingly.

The consideration of the district court judges came from examining case files in the names of Suryono alias Aweng, Anly Yusuf alias Mami, and Ramli Petrus alias Abeng. It was from this decision that Defendant Maha Nathy Naidu alias Rendy as the development of the BNN Investigator who was finally tried in Medan District Court, and the panel of judges could give consideration in the form of the assumption that the Defendant Maha Nathy Naidu alias Rendy had learned that the money he received was from proceeds of narcotics crime. in the form of methamphetamine.

Defendant Maha Nathy Naidu alias Rendy was convicted based on Article 137

${ }^{15}$ Ibid. 


\section{LAW REVIEW $\begin{aligned} & \text { E-ISSN: } 2722-3663 \\ & \text { Volume } 1 \text {, Issue 1, May 2020 }\end{aligned}$}

letter b. Law No. 35 of 2009 concerning Narcotics with imprisonment for 3 (three) years. So the Defendant Maha Nathy Naidu alias Rendy submitted an appeal to the Medan High Court through the Deed of Appeal No. 213 and 214/Akta.Pid/2012/ PN.Mdn. October 17, 2012.

After stating an appeal against Medan District Court Decision No. 1243/Pid.B/ 2012/PN.Mdn., Dated October 8, 2012, Defendant Maha Nathy Naidu made a memorandum of appeal with the following conclusions:

1. "Decision reading is imperfect

2. Decision of the Panel of Judges on October 10, 2012 No. 1243 / Pid.B / 2012 / PN.Mdn contrary to Article 200 of Indonesia Criminal Procedure Code

3. The decision of the Panel of Judges in a criminal case on behalf of Maha Nathy Naidu alias Rendy did not provide sufficient legal considerations

4. Decision of the Panel of Judges on October 10, 2012 No. 1243 / Pid.B / 2012 / PN.Mdn does not meet statutory requirements

5. The District Court Judges have violated the provisions of Article 185 paragraph (1) of Indonesia Criminal Procedure Code

6. Decision of the Panel of Judges dated October 10, 2012 Number 1243 / Pid.B / 2012 / PN.Mdn incorrectly applying the law

The consideration of the Judges in Hgh Court in the case remained essentially imposing criminal sanctions using Article 137 letter b. Law No. 35 of 2009 concerning Narcotics. However, different opinions regarding the criminal sentences on Defendant Maha Nathy Naidu alias Rendy, are as follows: ${ }^{16}$

"Considering, however, that the Panel of Judges does not agree with the First-rate Panel of Judges regarding the length of the criminal sentence imposed on the Defendant, bearing in mind that the Defendant's actions have supported the rampant circulation of narcotics in Indonesia, which according to the Panel of Judges of the High Court has plagued Indonesian society, and has involved and haunted all ethnicities, all religions, that have been made easy targets for international narcotics dealers, so that the eradication of narcotics distribution needs to be done more seriously, so that the criminal sanctions imposed by the First Level Judges are considered too light and not in accordance with public justice;

Considering, that in addition to incriminating matters as considered by the First Level Panel of Judges in the decision, the weighing considerations as described above can be used as a basis to increase the length of the criminal sentence that must be imposed on the Defendant, and the Panel of Judges has the opinion of the criminal as stated in the Law this decision is appropriate and fair for the Defendant and also for the people of Indonesia;

Considering, that accordingly the reasons of the Defendant's Legal Counsels in the conclusions of the appeal memory in points 3, 4 and 6 are not grounded and

${ }^{16}$ Decision of the Medan High Court No. 700 / Pid / 2012 / PT-Mdn., Dated January 8, 2013, p. 68-69. 


\section{LAW REVIEW $\begin{aligned} & \text { E-ISSN:2722-3663 } \\ & \text { Volume } 1 \text {, Isue } 1 \text {, May 2020 }\end{aligned}$}

therefore will be disregarded while the conclusions of the appeal memory in points 1,2 and 5 are not included in the scope of the examination in this level of appeal and therefore must also be set aside".

Judges at High Court in Medan based on the descriptions above has decided to fix only the criminal sentences to the Defendant while the rest of the decision can be upheld. So that the sentence handed down to Defendant Maha Nathy Naidu becomes 6 (six) years in prison.

In Medan District Court Decision No. 1243 / Pid.B / 2012 / PN.Mdn., Dated October 8, 2012 Jo. Decision of the Medan High Court No. 700 / Pid // 2012 / PTMdn., Dated January 8, 2013 has been decided Defendant Maha Nathy Naidu alias Rendy has been proven legally and convincingly guilty of committing the crime of "Receiving Placement in the Form of a Money Transfer that He Knows Comes from a Narcotics Criminal Act" as referred Article 137 letter b. Law No. 35 of 2009 concerning Narcotics.

Provisions applied in the case are provisions that originate from narcotics provisions, which when viewed further are very slight differences from the provisions of money laundering. The difference in the provision lies in the criminal act, if the Narcotics Act is specific to narcotics crime, whereas in the TPPU Law there is only the phrase "criminal act" which means it can be seen in Article 2 of the TPPU Law.

With regard to criminal provisions applied (whether using Narcotics Law or TPPU Law) is the authority of the investigator in this case the National Narcotics Agency (BNN) which conducts the development of narcotics cases. BNN sought the flow of funds by following the flow of payment money from drug dealers found downstream in the accounts opened by Defendant Maha Nathy Naidu alias Rendy.

The Money Laundering indictment in drug cases can be arranged in the form of subsidarity because the existing laws are still in conflict with the authority of investigators to handle the two different but related cases.

Difference in Decision of Medan District Court No. 1243 / Pid.B / 2012 / PN.Mdn., Dated October 8, 2012 with the Decision of the Medan High Court No. 700 / Pid / 2012 / PT.Mdn., Dated January 8, 2013, lies in imprisonment imposed. In the Medan District Court Decision, Defendant Maha Nathy Naidu was sentenced to imprisonment for 3 (three) years and 6 (six) months while the Medan High Court's Decision sentenced him to imprisonment for 6 ( $\mathrm{six}$ ) years. Both of these decisions have been right and correct according to law in determining the length of imprisonment imposed.

The difference in decisions in terms of imprisonment is due to the consideration of the Panel of Judges at the Medan High Court which is broader in scope than the First Level Judges at the Medan District Court for which there is no legal consideration at all. However, the legal considerations of the Panel of Judges have already departed from the context of the case being examined because they departed from the actions of the Defendant in favor of the widespread circulation of narcotics in Indonesia. The High Court of Judges could not prove whether the actions of Defendant Maha Nathy Naidu alias 


\section{LAW REVIEW $\begin{gathered}\text { E-ISSN: 2722-3663 } \\ \text { Volume } 1, \text { Issue 2, May 2020 }\end{gathered}$}

Rendy - was the one that was fueling the illicit trafficking of narcotics in Indonesia.

\section{CONCLUSION}

Judges considerations at the first level and appeals to money laundering and criminal offenses originating from drug crime related to Medan District Court Decision No. 1243 / Pid.B / 2012 / PN.Mdn., October 8, 2012 is that the consideration of the district court judges came from examining case files in the names of Suryono alias Aweng, Anly Yusuf alias Mami, and Ramli Petrus alias Abeng. It was from this decision that Defendant Maha Nathy Naidu alias Rendy as the development of the $\mathrm{BNN}$ Investigator who was finally tried in Medan District Court, and the panel of judges could give consideration in the form of the assumption that the Defendant Maha Nathy Naidu alias Rendy had learned that the money he received was from proceeds of narcotics crime. in the form of methamphetamine. Therefore, Defendant Maha Nathy Naidu alias Rendy was convicted based on Article 137 letter b. Law No. 35 of 2009 concerning Narcotics with imprisonment for 3 (three) years.Pada Putusan Pengadilan Negeri Medan No. 1243/Pid.B/2012/PN.Mdn., tertanggal 08 Oktober 2012 Jo. Putusan Pengadilan Tinggi Medan No. 700/Pid//2012/PT-Mdn., tertanggal 08 Januari 2013 telah diputus Terdakwa Maha Nathy Naidu alias Rendy telah terbukti secara sah dan meyakinkan bersalah melakukan tindak pidana "Menerima Penempatan Berupa Transfer Uang Yang Diketahuinya Berasal Dari Tindak Pidana Narkotika" sebagaimana dimaksud Pasal 137 huruf b. Undang-Undang No. 35
Tahun 2009 tentang Narkotika. Based on the legal principle of Lex Specialis Derogat Lex Generalis, the Panel of Judges who decided on the case must apply a criminal originating from more specific legal provisions.

\section{REFERENCESS}

Hafizi, M. Zainul., 2011, “Makalah Etika Bisnis Penegakan Hukum Terhadap Pencucian Uang di Indonesia", Jakarta : Universitas Indraprasta PGRI.

Husein, Yunus., "The Relationship Between the Illicit Circulation of Drugs and the Crime of Money Laundering", supporting paper of the Indonesian Delegation to the Forthy-Seventh Session of the Commission on Narcotics Drugs, held in Vienna March 15-22, (2004).

Indonesia, Law No. 10 of 1998 concerning Banking.

Indonesia, Law No. 35 of 2009 concerning Narcotics.

Indonesia, Law No. 8 of 1981 concerning the Criminal Procedure Code.

Indonesia, Law No. 8 of 2010 concerning Prevention and Eradication of Money Laundering Crimes.

Medan Bisnis Daily, "Moko Sentenced to 8 Years", published Monday, November 4, 2013.

Media Indonesia Daily, "Sudjono Iswahyudi: Legal Politics of Corruption Eradication: Lex Specialis Systematic Versus Lex Specialis Derogat Lege Generali", published Monday, 15 October, (2007). 
Nurhadiyanto, Lucky., 2010, "Pola Pencucian Uang Hasil Perdagangan Narkoba dan Pembalakan Liar", Jurnal Kriminologi Indonesia, Vol. 6, No. II, Agustus 2010. PPATK ELearning, tanpa tahun, "Modul ELearning 1 : Pengenalan Anti Pencucian Uang dan Pendanaan Terorisme", Jakarta : PPATK.

Reuter, Peter., And Edwin M. Truman, 2004, Chasing Dirty Money: The Fight Against Money Laundering, US: Automated Graphic Systems, Inc ..

RI Supreme Court, Medan District Court Decision No. 1243 / Pid.B / 2012 / PN.Mdn on October 8, 2012.

RI Supreme Court, RI Supreme Court Decision No. 1303 K / Pid.Sus / 2013 dated August 21, 2013.

Soesilo, R., 1985, Kitab Undang-Undang Hukum Pidana Serta KomentarKomentar Lengkap Pasal Demi Pasal, Bogor: Politeia.

Supreme Court of the Republic of Indonesia, Medan High Court Decision No. 700 / Pid / 2012 / PT.Mdn on January 8, 2013.

The Legal News Daily, "Mami BD Shabu Sentenced to 10 Years in Prison", was published Thursday, July 12, 2012.

The Republika daily, "Djoko Sarwoko: Between Narcotics and Money Laundering", was published Saturday, November 23, 2013. 